\title{
CRYPTOCOCCAL ANTIGENAEMIA IN ANTIRETROVIRAL THERAPY NAIVE PATIENTS WITH HUMAN IMMUNODEFICIENCY VIRUS INFECTION
}

\author{
Dibya Prasana Mohanty1, Dharma Niranjan Mishra², Dillip Kumar Pradhan³
}

${ }^{1}$ Assistant Professor, Department of Microbiology, Utkal University, SCB Medical College, Cuttack. ${ }^{2}$ Assistant Professor, Department of Anatomy, Utkal University, SCB Medical College, Cuttack. ${ }^{3}$ Senior Resident, Department of Medicine, Utkal University, SCB Medical College, Cuttack.

\begin{tabular}{l}
\hline ABSTRACT \\
BACKGROUND \\
Human Immunodeficiency Virus (HIV) related to cryptococcal meningitis in India is a leading cause of morbidity and mortality \\
among severely immunocompromised patients. \\
The aim of our study was to determine the prevalence of and risk factors for Cryptococcal antigenaemia among HIV-infected \\
adults attending ART clinic and medical emergency.
\end{tabular}

\section{MATERIALS AND METHODS}

This was a hospital-based cross-sectional and prospective study carried out among newly diagnosed and confirmed HIV-infected patients after taking written informed consent and due ethical approval. Results were presented in simple tables with distribution and percentages while $P$ value $\leq 0.05$ was considered as statistically significant.

\section{RESULTS}

Out of 100 patients, there were $65(65 \%)$ males and $35(35 \%)$ females in the study. The median age was being 35 years (range1867) followed by BMI $20.271 \mathrm{~m}^{2}$ (range15.1-26.48) and CD4 count 196 (range 6 -780) cells/mm3. Out of 100 patients, seven (7\%) were positive for cryptococcal antigen (CRAG). Six (85.71\%) of them were CRAG positives with CD4+ cell count less than 100 cells, while $1(14.28 \%)$ had count above 100 cells $/ \mathrm{mm}^{3}$. There were $4(23.5 \%)$ SCRAG+ out of 17 symptomatic cases and 3 (3.6\%) were SCRAG+ out of 83 asymptomatic patients with statistical significance $(\mathrm{p}<0.015)$. The symptoms of fever, headache, vomiting and neck rigidity are significantly associated with Cryptococcal antigenaemia $(\mathrm{p}<0.05)$.

\section{CONCLUSION}

All ART naive adults having CD4 count $<100$ cells $/ \mathrm{mm}^{3}$ should be screened for serum Cryptococcal antigen followed by presumptive antifungal therapy if serum Cryptococcal antigen is positive.

\section{KEYWORDS}

Cryptococcal Antigenaemia (CRAG), CD4- Cluster Differentiation, Human Immunodeficiency Virus (HIV).

HOW TO CITE THIS ARTICLE: Mohanty DP, Mishra DN, Pradhan DK. Cryptococcal antigenaemia in antiretroviral therapy naïve patients with human immunodeficiency virus infection. J. Evolution Med. Dent. Sci. 2017;6(90):6277-6281, DOI: $10.14260 /$ jemds/2017/1365

\section{BACKGROUND}

Human Immunodeficiency Virus (HIV) infection is a global pandemic, with cases reported from virtually every country. World Health Organization (WHO) has estimated 34.0 million (31.4-35.9) global people living with HIV in 2011. Based on HIV Sentinel Surveillance 2008-09, it is estimated that India has 23.9 lakh people infected with HIV. Human Immunodeficiency Virus infection was first reported in India in the state of Tamil Nadu in 1986, since then the cases of Cryptococcal Meningitis (CM) have also increased. ${ }^{1}$ Morbidity and mortality in HIV patients is mostly caused by opportunistic infections (OI) that occur due to lowered immune defences of the patients associated with decreased CD4 counts. Among these, meningitis with HIV has an important impact causing considerable morbidity and mortality. Meningitis associated with HIV infection can be

'Financial or Other Competing Interest': None.

Submission 12-10-2017, Peer Review 05-11-2017,

Acceptance 11-11-2017, Published 20-11-2017.

Corresponding Author:

Dharma Niranjan Mishra,

Flat No. 3-B, Neelamani Enclave,

Professor Pada, Post- College Square,

Cuttack-753003.

E-mail: dharmaniranjan.mishra08@gmail.com

DOI: $10.14260 /$ jemds $/ 2017 / 1365$

\section{(c) $(1) \odot$}

classified according to aetiologic agents as fungal, tubercular, syphilitic and pyogenic. The most common OI in HIV patients in India is either tubercular or fungal. ${ }^{2}$ Cryptococcosis is a fungal disease caused by Cryptococcus neoformans (CN), which begins as droplet infection in the respiratory tract and eventually spreads to central nervous system to produce meningitis (CM).

Cryptococcal meningitis (CM) is one of the presenting manifestations of Acquired Immune Deficiency Syndrome (AIDS). ${ }^{3}$ Cryptococcal meningitis is one of the most common OI among HIV-infected individuals, with an estimated 10 lakh cases of HIV associated CM and 6 lakh deaths every year or more than 1700 deaths everyday. ${ }^{4}$ Despite cryptococcal disease accounting for $13-44 \%$ of deaths in HIV-infected patients, cryptococcal diseases continue to be grossly underdiagnosed. ${ }^{5}$ Recent data indicates that the incidence of cryptococcal infection is high in India. ${ }^{6}$ It is the leading infectious cause of meningitis in patients with AIDS and is the initial AIDS defining diagnosis in approximately $2 \%$ of patients, mostly occurring in those with CD4 counts less than 100 cells $/ \mathrm{mm}^{3.7}$

Cryptococcal antigen (CRAG), a biological marker for Cryptococcal infection, is detectable in sera a median of 3 weeks (range 5 - 234 days) before symptoms of meningitis appear. $^{8}$ Positive Cryptococcal antigenaemia is an 
independent predictor of $\mathrm{CM}$ and death in patients with severe immunosuppression. ${ }^{9}$ This asymptomatic period before development of symptomatic meningitis provides a window of opportunity to treat patients and potentially prevent fatal Cryptococcal disease. CRAG detection is highly sensitive as compared with microscopy and culture.10 The best prophylaxis to prevent $\mathrm{OI}$ is an immune reconstitution with anti-retro viral therapy (ART). In areas of high prevalence, the CM screening prior to ART is necessary for potential early diagnosis and treatment. This could decrease the risk of Immune Reconstitution Inflammatory Syndrome (IRIS). The WHO has recently released "Rapid Advice" guidelines for Cryptococcal disease among persons living with HIV. Early diagnosis is key to reduce mortality due to Cryptococcal disease. A major WHO recommendation is implementation of SCRAG screening and presumptive antifungal therapy (typically oral fluconazole) in those with a positive diagnostic test among ART naïve adults with a CD4 count less than $100 \mathrm{cell} / \mathrm{mm}^{3}$ in areas with a high prevalence of Cryptococcal disease (>3\%).

One limitation to implementing the WHO guidelines is that currently very less data exists on the extent of Cryptococcal infection in India. Hence, this prompted the study which aims at finding occurrence of and risk factors associated with Cryptococcal antigenaemia in ART naïve patients with HIV. The purpose of our study was to determine the prevalence of and risk factors for Cryptococcal antigenaemia among HIV-infected adults attending ART clinic and medical emergency at SCB Medical College and Hospital, Cuttack.

\section{MATERIALS AND METHODS}

Study Design: Cross-sectional observational study with asking research questionnaire developed for this purpose.

\section{Study Location}

This study was undertaken among newly diagnosed antiretroviral therapy naïve HIV/AIDS infected patients at the Postgraduate Department of Medicine, SCB Medical College, Cuttack after taking written informed consent. Hundred patients admitted in the medical wards and visiting ART clinic were considered for this study from May 2016 to Apr 2017. The screening test was done for serum cryptococcal antigen (SCRAG).

\section{Inclusion Criteria}

ART naïve patients $\geq 18$ years documented for HIV infection and confirmed by a series of 3 tests as per NACO Guidelines (First by dot immunoassay followed by two different immunochromatographic tests).

\section{Exclusion Criteria}

Previously diagnosed Cryptococcosis patients on fluconazole therapy and satisfying the above criteria.

\section{Ethical Issues}

This study confirms to the ethical principles of medical research developed by the World Medical Association Declaration of Helsinki. Ethical clearance was given by the Institutional Ethics Committee of SCB Medical College, Cuttack.

Data Analysis: All data obtained with questionnaire and microbiological culture analysis were analysed using the statistical software SSPS 16.0. The Chi-square test was used to compare between two groups. Statistical significance was accepted when $\mathrm{P}$ value is $\leq 0.05$ and the Univariate and multivariate logistic regression analyses were done to assess risk factors for a positive cryptococcal antigenaemia. Risk factors with possible significance and known to be associated with cryptococcal disease were included in the present study.

\section{RESULTS}

The mean age of the study population was being $36.14 \pm$ 10.42 years (ranges 18-67 years) and median was being 35 years. The mean body mass index (BMI) of our study population was $20.54 \mathrm{~kg} / \mathrm{m}^{2} \pm 2.72$ (ranges 15.1 to 26.48 $\mathrm{kg} / \mathrm{m}^{2}$ ). The present study population had mean cluster differentiation (CD4) count of 233 cells $/ \mathrm{mm}^{3} \pm 176$ (ranges 6 to 780 cells $/ \mathrm{mm}^{3}$ ) (Table 1 ).

\begin{tabular}{|c|c|c|c|c|c|}
\hline Characteristic & No. & Mean \pm SD & Median & Range Min-Max & I Q Range \\
\hline Age in years & 100 & $36.14 \pm 10.42$ & 35 & $18-67$ & $30.0-42$ \\
\hline BMI $\left(\mathrm{kg} / \mathrm{m}^{2}\right)$ & 100 & $20.54 \pm 2.72$ & 20.271 & $15.1-26.48$ & $19.13-22.36$ \\
\hline CD4 count cells $/ \mathrm{mm}^{3}$ & 100 & $233.06 \pm 176.13$ & 196 & $6-780$ & $70.5-355.5$ \\
\hline \multicolumn{6}{|c|}{ T.Q -Interquartile range, CD4 -cluster differentiation (cells/mm ${ }^{3}$ ) and BMI- body mass index } \\
\hline \multicolumn{6}{|c}{ Table 1. Age, BMI and CD4 Count Characteristics Distribution of Study Population } \\
\hline
\end{tabular}

The maximum number of patients were from age group of 30-39 years (42\%) followed by $18-30$ years $(24 \%), 40-50$ years $(20 \%)$ and $>50$ years $(14 \%)$. There were $65 \%$ males (65 out of 100) and 35\% (35 out of 100) females in our study and the male to female ratio was being 1.86. Maximum patients had BMI in between 18.5 to $25 \mathrm{~kg} / \mathrm{m}^{2}$ followed by
$20 \%$ with $<18.5 \mathrm{~kg} / \mathrm{m}^{2}$ and $6 \%$ with $>25 \mathrm{~kg} / \mathrm{m}^{2}$. In the present study, $31 \%$ of individuals had CD4 count $<100$ cells $/ \mathrm{mm}^{3}$ and $69 \%>100$ cells $/ \mathrm{mm}^{3}$ were observed. Signs and symptoms of meningitis were found in $17 \%$ and others were asymptomatic (Table 2).

\begin{tabular}{|c|c|c|}
\hline Age in years & Number(n) & Percentage \\
\hline $18-29$ & 24 & $24 \%$ \\
\hline $30-39$ & 42 & $2 \%$ \\
\hline $40-49$ & 20 & $20 \%$ \\
\hline$\geq 50$ & 14 & $14 \%$ \\
\hline Male & 65 & $65 \%$ \\
\hline Female & 35 & $35 \%$ \\
\hline BMI $\left(\mathrm{kg} / \mathrm{m}^{2}\right)<18.5$ & 20 & $20 \%$ \\
\hline
\end{tabular}




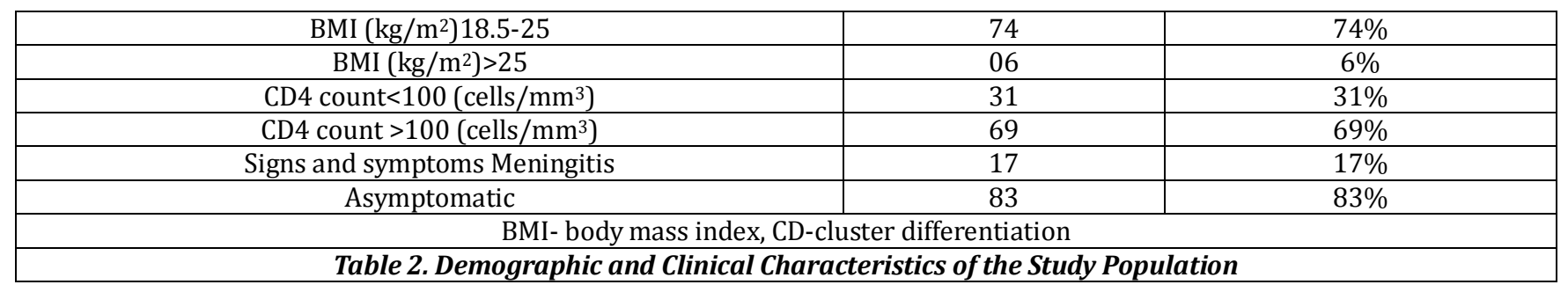

The mean age among patients with serum cryptococcal antigen positive (SCRAG +) was 43.71 years as compared to $35.57 \%$ in cryptococcal antigen negative (SCRAG-) and this difference was statistically significant $(\mathrm{p}-0.046)$. The mean BMI of SCRAG+ patients and SCRAG- were $20.22 \pm 2.64 \mathrm{~kg} / \mathrm{m}^{2}$ and $20.56 \pm 2.74$ respectively, which is statistically insignificant. The mean CD4 count of SCRAG- patients $(246 \pm$ $175.0)$ cells $/ \mathrm{mm}^{3}$ was higher than SCRAG+ patients $(56.57 \pm$ 56.0). The median CD4 count was being forty one (41 cells $/ \mathrm{mm}^{3}$ ) in SCRAG+ and 203 cells $/ \mathrm{mm}^{3}$ in SCRAG- patients. The difference was statistically significant $(p=0.001)$ (Table 3).

\begin{tabular}{|c|c|c|c|c|c|c|}
\hline Type & \multicolumn{3}{|c|}{ SCRAG Positive(n=7) } & \multicolumn{3}{|c|}{ SCRAG Negative(n=93) } \\
\hline Characteristic & Age in years & $\begin{array}{c}\text { BMI } \\
\left(\mathrm{kg} / \mathrm{m}^{2}\right)\end{array}$ & $\begin{array}{l}\text { CD4 count } \\
\text { (cells } / \mathrm{mm}^{3} \text { ) }\end{array}$ & Age in years & BMI $\left(\mathrm{kg} / \mathrm{m}^{2}\right)$ & $\begin{array}{c}\text { CD4 count } \\
\text { (cells/mm3) }\end{array}$ \\
\hline Mean \pm S.D & $43.71 \pm 13.94$ & $20.22 \pm 2.64$ & $56.57 \pm 56.0$ & $35.57 \pm 9.978$ & $20.56 \pm 2.74$ & $246.34 \pm 175.0$ \\
\hline Median & 40 & 19.1 & 41 & 35 & 20.5 & 203 \\
\hline Range & $26-67$ & $16.9-23.9$ & $6-168$ & $18-64$ & $15.1-26.5$ & $15-780$ \\
\hline I Q Range & $35.5-52.25$ & $18.7-22.8$ & $19.0-78.3$ & $29.75-42.0$ & $19.3-22.4$ & $91-370.0$ \\
\hline $\mathrm{P}$ value & 0.046 & 0.750 & 0.001 & 0.046 & 0.750 & 0.001 \\
\hline
\end{tabular}

SCRAG - serum cryptococcal antigen, I Q Range -Interquartile range, CD4 count-cluster differentiation count (cells $/ \mathrm{mm}^{3}$ ), $\mathrm{P}$ value

Table 3. Age, BMI and CD4 Count Characteristics Distribution of SCRAG Positive and SCRAG Negative Patients

Out of 65 males, 5 (7.7\%) were positive for SCRAG and 2 (5.7\%) were positive among 35 female patients. Majority of the study population were literate $(77 \%)$ and doing unskilled work (63\%). Maximum cases $(88,88 \%)$ of the study population were married. The sexual transmission route for HIV infection was found to be $99 \%$ where the duration of illness is longer. The majority of SCRAG+ ( 6 out of 7) patients had BMI between 18.5 to $25 \mathrm{~kg} / \mathrm{m}^{2}$ as compared to the other groups, but the difference was not statistically significant. Out of 33 patients who had CD4 count $<100$ cells $/ \mathrm{mm}^{3}, 6$ $(19.35 \%)$ were positive for SCRAG and significant statistically ( $\mathrm{p}<0.003$ ). Of sixty-nine patients who had CD4 count $>100$ cells $/ \mathrm{mm}^{3}$, $1(1.45 \%)$ was positive for SCRAG having statistically significance $(\mathrm{p}<0.012)$. Patients with cryptococcal antigenaemia were more prone to have CD4 count $<100$ cells $/ \mathrm{mm}^{3}$ (Table 4).

\begin{tabular}{|c|c|c|c|c|}
\hline Parameters & SCRAG+ (n=7) & SCRAG- (93) & Total & P Value \\
\hline Male & $5(7.7)$ & $60(92.3 \%)$ & $65(100 \%)$ & 1.00 \\
\hline Female & $2(5.7 \%)$ & $33(94.3 \%)$ & $35(100 \%)$ & 1.00 \\
\hline Illiterate & $2(8.7 \%)$ & $21(91.3 \%)$ & $23(100 \%)$ & 0.660 \\
\hline Education $<10^{\text {th }}$ standard & $2(4.5 \%)$ & $42(95.5 \%)$ & $44(100 \%)$ & 0.660 \\
\hline Education $>10^{\text {th }}$ standard & $3(9.1 \%)$ & $30(90.9 \%)$ & $33(100 \%)$ & 0.660 \\
\hline Skilled worker & $3(8.1 \%)$ & $34(91.9 \%)$ & $37(100 \%)$ & 0.708 \\
\hline Unskilled worker & $4(6.3 \%)$ & $59(93.7 \%)$ & $63(100 \%)$ & 0.708 \\
\hline Married & $6(6.8 \%)$ & $82(93.2 \%)$ & $88(100 \%)$ & 1.00 \\
\hline Unmarried & $1(8.3 \%)$ & $11(91.7 \%)$ & $12(100 \%)$ & 1.00 \\
\hline Recent onset of the disease & $7(9.9 \%)$ & $64(90.1 \%)$ & $71(100 \%)$ & 0.104 \\
\hline Past history of the disease & $0(0 \%)$ & $29(100 \%)$ & $29(100 \%)$ & 0.104 \\
\hline BMI<18.5 kg/m ${ }^{2}$ & $1(4.5 \%)$ & $19(95.5 \%)$ & $20(100 \%)$ & 0.700 \\
\hline BMI 18.5-25.0 kg/m ${ }^{2}$ & $6(8.2 \%)$ & $68(91.8 \%)$ & $74(100 \%)$ & 0.700 \\
\hline BMI $>25.1 \mathrm{~kg} / \mathrm{mm}^{2}$ & $0(0 \%)$ & $6(100 \%)$ & $6(100 \%)$ & 0.700 \\
\hline CD4<100 cells $/ \mathrm{mm}^{3}$ & $6(19.35 \%)$ & $27(80.65 \%)$ & $33(100 \%)$ & 0.001 \\
\hline CD4>100 cells $/ \mathrm{mm}^{3}$ & $1(1.45 \%)$ & $68(98.55 \%)$ & $69(100 \%)$ & 0.001 \\
\hline Symptomatic Cr Ag & $4(23.5 \%)$ & $13(76.5 \%)$ & $17(76.5 \%)$ & 0.015 \\
\hline Asymptomatic Cr Ag & $3(3.6 \%)$ & $80(96.4 \%)$ & $83(96.4 \%)$ & 0.015 \\
\hline \multicolumn{2}{|r|}{ Table 4. Comparison of Different Parameters in SCRAG+ and SCRAG- Study Group } \\
\hline
\end{tabular}

Univariate analysis showed fever $(\mathrm{p}<0.005$, OR $23.368, \mathrm{CI}$ 2.652-205.398), headache $(\mathrm{p}<0.010$, OR 8.205 , CI 1.644$40.950)$, vomiting $(\mathrm{p}<0.004$, OR 13.200, CI 2.300-75.750), neck rigidity $(\mathrm{p}<0.014$, OR 7.969, CI 1.510-42.044) and CD4 count $<100$ cells $/ \mathrm{mm}^{3} \quad(\mathrm{p}<0.012$, OR 16.320 , CI 1.871-
142.374) were significantly associated with Cryptococcal antigenaemia. However, age, sex, socioeconomic status, marital status, altered mental status, duration of HIV infection, BMI and CD4 count $<200$ cells $/ \mathrm{mm}^{3}$ were not 
significantly associated with cryptococcal antigenaemia (Table 5).

\begin{tabular}{|c|c|c|c|c|}
\hline \multirow[t]{2}{*}{ Risk Factor } & \multirow[t]{2}{*}{$P$ value } & \multirow[t]{2}{*}{$\begin{array}{l}\text { Odds } \\
\text { Ratio } \\
\end{array}$} & \multicolumn{2}{|c|}{$\begin{array}{l}\text { 95\% CI for Odds } \\
\text { Ratio }\end{array}$} \\
\hline & & & Lower & Upper \\
\hline Age in years & 0.055 & 1.072 & 0.999 & 1.151 \\
\hline Male sex & 0.713 & 0.727 & 0.134 & 3.957 \\
\hline $\begin{array}{c}\text { Education }<8^{\text {th }} \\
\text { standard }\end{array}$ & 0.489 & 0.488 & 0.064 & 3.712 \\
\hline $\begin{array}{c}\text { Education }>8^{\text {th }} \\
\text { standard }\end{array}$ & 0.913 & 1.086 & 0.167 & 7.085 \\
\hline Married & 0.847 & 0.805 & 0.088 & 7.237 \\
\hline $\mathrm{BMI} \mathrm{kg} / \mathrm{m}^{2}$ & 0.747 & 0.954 & 0.718 & 1.268 \\
\hline $\begin{array}{c}\text { CD4 count } \\
<50 \text { cells } / \mathrm{mm}^{3} \\
\end{array}$ & 0.001 & 20.750 & 3.548 & 121.385 \\
\hline $\begin{array}{l}\text { CD } 4 \text { count }<100 \\
\text { cells } / \mathrm{mm}^{3}\end{array}$ & 0.012 & 16.320 & 1.871 & 142.374 \\
\hline $\begin{array}{l}\text { CD } 4 \text { count }<200 \\
\text { cells } / \mathrm{mm}^{3}\end{array}$ & 0.053 & 17.414 & 0.967 & 313.749 \\
\hline Fever & 0.005 & 23.368 & 2.652 & 205.368 \\
\hline Headache & 0.010 & 8.205 & 1.644 & 40.950 \\
\hline vomiting & 0.004 & 13.200 & 2.300 & 75.750 \\
\hline Neck rigidity & 0.014 & 7.969 & 1.510 & 42.044 \\
\hline $\begin{array}{l}\text { Altered mental } \\
\text { status }\end{array}$ & 0.617 & 1.771 & 0.189 & 16.595 \\
\hline \multicolumn{5}{|c|}{ C.I-95\% Confidence Intervals of Odds Ratios } \\
\hline $\begin{array}{r}\text { Table 5. Univ } \\
\text { Cryptococcal Anti }\end{array}$ & & & sk Facto & $\begin{array}{l}\text { for } \\
\text { Patients }\end{array}$ \\
\hline
\end{tabular}

In multivariate analysis, CD 4 count $<50$ cells $/ \mathrm{mm}^{3}$ was acting as independent risk factor for cryptococcal antigenaemia ( $p<0.019$, OR 17.769, CI 1.594-198.042) (Table 6). However, the other factors did not contribute to independent risk factors in the present study.

\begin{tabular}{|c|c|c|c|c|}
\hline Risk factor & $P$ value & $\begin{array}{l}\text { Odds } \\
\text { Ratio } \\
\end{array}$ & \multicolumn{2}{|c|}{$\begin{array}{l}\text { 95\% C.I for Odds } \\
\text { Ratio } \\
\end{array}$} \\
\hline Fever & 0.074 & 12.736 & 0.780 & 208.014 \\
\hline Headache & 0.991 & 1.022 & 0.022 & 47.211 \\
\hline vomiting & 0.293 & 4.474 & 0.274 & 73.150 \\
\hline Neck rigidity & 0.568 & 17.761 & 1.594 & 198.042 \\
\hline $\begin{array}{c}\text { CD4 count }<50 \\
\text { cells } / \mathrm{mm}^{3}\end{array}$ & 0.019 & 17.769 & 1.594 & 198.042 \\
\hline \multicolumn{5}{|c|}{ 95\% Confidence Intervals of Odds Ratios } \\
\hline
\end{tabular}

\section{DISCUSSION}

In the present study, overall prevalence of Cryptococcal antigenaemia is found to be $7 \%$, which is comparable to the studies in Uganda (5-10\%), ${ }^{11}$ South Africa (7\%)12 and Kenya(7\%), ${ }^{13}$ which confirms that India has high rates of cryptococcal disease in HIV-infected patients in comparison to tuberculosis. The prevalence of patients with CD4 count less than 100 cells $/ \mathrm{mm}^{3}$ is $19.35 \%$ in the present study, which coincides with the study of Otella et al ${ }^{13}$ in Uganda. Out of 17 meningitis cases, $4(23.52 \%)$ cases are having cryptococcal meningitis as compared with Gomerep et al. ${ }^{14}$ We observed the overall mean age being 36 years (range 18-67 years) and 43 years in SCRAG positive group as compared to 35 years in SCRAG negative group $(\mathrm{p}<0.046)$. On univariate analysis, we did not find advanced age as a risk factor. ${ }^{15}$ There are 65 males and 35 females and the $\mathrm{M}$ : $\mathrm{F}$ ratio being 1.86:1 as compared with earlier studies. ${ }^{15}$ Most of the study population has average income and literate doing unskilled work but they do not have any significant difference with positivity of SCRAG $(\mathrm{p}>0.05)$.

In the present study, all patients with SCRAG+ are recently diagnosed for HIV and 14 (19.71\%) out of 71 have advanced disease and 25 (35.21\%) patients have CD4 count less than 100 cells $/ \mathrm{mm}, 3$ which may be due to lack of IEC (information, education and communication) activities to reach all section of population of our country.

There are 17 symptomatic patients out of which 4 (23.5\%) are SCRAG+ and out of 83 asymptomatic patients 3 (3.6) are SCRAG+, which is statistically significant $(p<0.015) .{ }^{10}$ The symptoms of fever, headache, vomiting and neck rigidity are significantly associated with Cryptococcal antigenaemia $(\mathrm{p}<0.05) .16$

The mean BMI of the study population is $20.54 \mathrm{~kg} / \mathrm{m}^{2}$. The SCRAG + has showed BMI $20.22 \mathrm{~kg} / \mathrm{m}^{2}$ whereas SCRAGcases $20.56 \mathrm{~kg} / \mathrm{m}^{2}$, which is definitely higher than the previous researchers $\left(<15.4 \mathrm{~kg} / \mathrm{m}^{2}\right)$ Oyella et. al and Micol et al. ${ }^{13,17}$ They have included patients with more advanced disease and lesser CD4 counts.

The median CD4 count of SCRAG+ individuals is 41 cells $/ \mathrm{mm}^{3}$ (mean 56, range 6-168, IQR 19.000-78.250) as compared to 203 cells $/ \mathrm{mm}^{3}$ (mean 246, range 15-780, IQR 91-370) in SCRAG- individuals $(\mathrm{p}<0.001)$ in Andama et al study. 18 The CD 4 count $<100$ cells $/ \mathrm{mm}^{3}$ is found in 31 patients out of which $6(19.35 \%)$ are SCRAG+ in comparison to $\mathrm{CD} 4$ count $>100$ cells $/ \mathrm{mm}^{3}$ in which $1.45 \%$ are SCRAG+. On univariate analysis, CD 4 count $<100$ cells $/ \mathrm{mm}^{3}$ is significantly associated with positive SCRAG ( $\mathrm{p}<0.012$, OR- 16.320, 95\% CI 1.871-142.374) as studied by Tenna et al,11 but 67 cases in multivariate analysis do act as independent risk factor for Cryptococcal antigenaemia in Oyella et al study.13 We observed high prevalence of subclinical infection 3 (3.6\%) in the present study irrespective of CD4 count. Antigenaemia is not only predictive of the development of cryptococcal meningitis but also an independent predictor of mortality. ${ }^{12}$

\section{CONCLUSION}

There is a high prevalence of symptomatic Cryptococcal antigenaemia (7\%) and asymptomatic Cryptococcal antigenaemia (3.6\%) in ART naïve HIV patients irrespective of CD4 count. There is a high prevalence of Cryptococcal antigenaemia (19.35\%) in ART naïve patients having CD4 count $<100$ cells $/ \mathrm{mm}^{3}$. Symptoms like fever, headache, vomiting and neck rigidity have been observed in patients having CD4 count $<100$ cells $/ \mathrm{mm}^{3}$, significant association with Cryptococcal antigenaemia on univariate analysis seen. Cryptococcal antigenaemia is not only predictive of the development of cryptococcal meningitis in HIV patients but also an independent predictor of mortality. All ART naïve adults having CD 4 count $<100$ cells $/ \mathrm{mm}^{3}$ should be screened for serum Cryptococcal antigen followed by presumptive antifungal therapy if serum Cryptococcal antigen is positive. There is a need to strengthen IEC (information, education and communication) activities and increase routine counselling and testing of the patients attending ART clinics in Odisha.

\section{Abbreviations}

SCRAG- serum cryptococcal antigenaemia, CD4- cluster differentiation, HIV- Human Immunodeficiency Virus, WHOWorld Health Organization, CM- Cryptococcal meningitis , OI- 
opportunistic infections, AIDS- Acquired Immune Deficiency Syndrome, IQR- Interquartile range, CD4- cluster differentiation (cells $/ \mathrm{mm}^{3}$ ) and BMI- body mass index and C.I-95\% Confidence Intervals of Odds Ratios.

\section{REFERENCES}

[1] Simoes EA, Babu GP, John TJ, et al. Evidence for HTLV-3 infection in prostitutes in Tamil Nadu (India). Indian J Med Res 1987;85:335-8.

[2] Sharma SK, Kadhiravan T, Banga A, et al. Spectrum of clinical disease in a series of 135 hospitalised HIVinfected patients of north India. BMC Infected Dis 2004;4:52.

[3] Lakshmi V, Sudha T, Teja VD, et al. Prevalence of central nervous system cryptococcosis in human immunodeficiency virus reactive hospitalized patients. Indian Med Microbiol 2007;25(2):146-9.

[4] Park BJ, Wannemuehler KA, Marston BJ, et al. Estimation of current global burden of cryptococcal meningitis among persons living with HIV/AIDS. AIDS 2009;23(4):525-30.

[5] Churchyard GJ, Kleinschmidt I, Corbett EL, et al. Factors associated with an increased case-fatality rate in HIVinfected and non-infected South African gold miners with pulmonary tuberculosis. Int J Tuberc Lung Dis 2000;4(8):705-12.

[6] Manoharan G, Padmavathy BK, Vasanthi S, et al. Cryptococcal meningitis among HIV-infected patients. Indian J Med Microbiol 2001;19(3):157-8.

[7] Rao VK, Thomas FP. Neurological complications of HIV/AIDS. BETA 2005;17(2):37-46.

[8] French N, Gray K, Watera C, et al. Cryptococcal infection in a cohort of HIV-1-infected Ugandan adults. AIDS 2002;16(7):1031-8.

[9] Liechty CA, Solberg P, Were W, et al. Asymptomatic serum cryptococcal antigenemia and early mortality during antiretroviral therapy in rural Uganda. Trop Med Int Health 2007;12(8):929-35.
[10] Kambugu A, Meya DB, Rhein J, et al. Outcomes of cryptococcal meningitis in Uganda before and after the availability of highly active antiretroviral therapy. Clin Infect Dis 2008;46(11):1694-701.

[11] Tenna A. Screening for cryptococcal infection in HIVinfected patients visiting HIV clinics at two hospitals in Addis Ababa, Ethiopia. 3 ${ }^{\text {rd }}$ Methods in International Neuro AIDS Rearch 2011.

[12] Tassie JM, Pepper L, Fogg C, et al. Systematic screening of cryptococcal antigenemia in HIV-positive adults in Uganda. J Acquir Immune Defic Syndr 2003;33(3):4112.

[13] Oyella J, Meya D, Bajunirwe F, et al. Prevalence and factors associated with cryptococcal antigenemia among severely immunosuppressed HIV-infected adults in Uganda: a cross sectional study. J Int AIDS Soc 2012;15(1):15.

[14] Gomerep SS, Idoko JA, Ladep NG, et al. Frequency of cryptococcal meningitis in HIV-1 infected patients in north central Nigeria. Niger J Med 2010;19(4):395-9.

[15] Osazuwa F, Dirisu JO, Okuonghae PE, et al. Screening for cryptococcal antigenenemia in anti-retroviral naïve AIDS patient in Benin City, Nigeria. Oman Med J 2012;27(3):228-31.

[16] Beyene T, Woldeamanuel Y, Asrat D, et al. Comparison of cryptococcal antigenemia between antiretroviral naïve and antiretroviral experienced HIV positive patients at two hospitals in Ethiopia. PLoS One 2013;8(10):e75585.

[17] Micol R, Lortholary O, Sar B, et al. Prevalence, determinants of positivity, and clinical utility of cryptococcal antigenemia in Cambodian HIV-infected patients. J Acquir Immune Defic Syndr 2007;45(5):5559.

[18] Andama AO, den Boon S, Meya D, et al. Prevalence and outcomes of cryptococcal antigenemia in HIVseropositive patients hospitalized for suspected tuberculosis in Uganda. J Acquir Immune Defic Syndr 2013;63(2):189-94. 